\title{
Romiplostim for Thrombocytopenia Following Allogeneic Stem Cell Transplantatio Case Series
}

Guido Lancman, $\mathrm{MD}^{1}$; Alexander Coltoff, MD¹; Amir Steinberg, MD²

1Department of Internal Medicine, Icahn School of Medicine at Mount Sinai, NY, NY, 10029

2Division of Hematology and Oncology, Mount Sinai Hospital, NY, NY, 10029

\section{Introduction}

- Thrombocytopenia is a relatively common complication following allogeneic hematopoietic stem cell transplantation

- It is associated with increased bleeding, transfusion requirements, chronic graft-versus-host disease and all-cause mortality

- Currently no approved treatments outside of supportive transfusions

- We report on the outcomes of 5 patients who received romiplostim for either primary engraftment failure or secondary failure of platelet recovery (SFPR)

\section{Methods}

- Retrospective case series of post-HSCT patients at our institution with either primary platelet engraftment failure or SFPR who were treated with romiplostim 5 patients identified

Dose was $1 \mathrm{mcg} / \mathrm{kg}$, increased by $1 \mathrm{mcg} / \mathrm{kg}$ per week at physician's discretion

- Response to romiplostim and platelet recovery were defined as 7 consecutive days of platelet count $>50 \times 10^{9} / \mathrm{L}$ with transfusion independence
Results

- 4 out of the 5 patients demonstrated a response to romiplostim

- Responses to romiplostim were sustained in the absence of significant bone marrow disease, which was found to contribute to recurrent thrombocytopenia

- Romiplostim was well-tolerated overall; one patient developed minimal fibrotic changes on bone marrow biopsy post-romiplostim

Table 1: Patient Characteristics and Response to Romiplostim

Table 1: Patient Characteristics and Response to
Romiplostim
\begin{tabular}{|l|l|l|l|l|l|l|l|l|}
\hline Patient & Age/Gender & $\begin{array}{l}\text { Indication } \\
\text { for } \\
\text { Transplant }\end{array}$ & $\begin{array}{l}\text { Donor } \\
\text { Source/ } \\
\text { Match }\end{array}$ & $\begin{array}{l}\text { Primary } \\
\text { Failure } \\
\text { or SFPR }\end{array}$ & $\begin{array}{l}\text { \# RPM } \\
\text { doses }\end{array}$ & $\begin{array}{l}\text { Time to } \\
\text { Response } \\
\text { (days) }\end{array}$ & $\begin{array}{l}\text { Duration } \\
\text { of } \\
\text { Response } \\
\text { (days) }\end{array}$ & Complications \\
\hline 1 & $41 / \mathrm{M}$ & Ph+ B-ALL & $\begin{array}{l}\text { dUCB: } \\
4 / 6,4 / 6\end{array}$ & SFPR & 16 & 42 & 22 & No \\
\hline 2 & $39 / \mathrm{M}$ & $\begin{array}{l}\text { Aplastic } \\
\text { anemia }\end{array}$ & $\begin{array}{l}\text { MRD, } \\
10 / 10\end{array}$ & Primary & 17 & n/a & n/a & No \\
\hline 3 & $41 / \mathrm{F}$ & AML, M5 & $\begin{array}{l}\text { dUCB: } \\
4 / 6,4 / 6\end{array}$ & Primary & 8 & 27 & $\begin{array}{l}407 \\
\text { (ongoing) }\end{array}$ & $\begin{array}{l}\text { Focal } 0-1+ \\
\text { fibrosis on } \\
\text { BMBx }\end{array}$ \\
\hline 4 & $39 / \mathrm{M}$ & B-ALL & $\begin{array}{l}\text { dUCB: } \\
5 / 6,6 / 6\end{array}$ & SFPR & 7 & 14 & 104 & No \\
\hline 5 & $35 / F$ & B-ALL & $\begin{array}{l}\text { dUCB: } \\
4 / 6,6 / 6\end{array}$ & Primary & 10 & 58 & 404 & No \\
\hline
\end{tabular}

Discussion/ Conclusions

- Our series adds to the generally positive literature regarding romiplostim in this setting, as 4 out of the 5 patients demonstrated a platelet response

- Response was seen in both primary engraftment failure and SFPR; however romiplostim was not effective in the setting of significant bone marrow disease

- Although well-tolerated in this series, romiplostim needs to be evaluated in a randomized clinical trial in this setting to fully assess safety and efficacy 